\title{
Risk Committee, Corporate Risk-Taking and Firm Value
}

\author{
Md Borhan Uddin Bhuiyan, Muhammad A. Cheema, Yimei Man
}

\begin{abstract}
We empirically examine the impact of the stand-alone risk committee on corporate risk-taking and firm value. We argue that the existence of a stand-alone risk committee enhances the quality of corporate governance which results in improved investor protection by reducing corporate risk-taking and enhancing firm value. We find several measures of risk-taking decline significantly for firms that have a stand-alone risk committee compared with firms that have a joint audit and risk committee. We also find that the presence of a stand-alone risk committee is positively associated with firm value. The evidence is consistent with the proposition that the firms with a stand-alone risk committee can effectively evaluate potential risks and implement a proper risk management system.
\end{abstract}

Keywords: stand-alone risk committee; corporate risk-taking; firm value; Australia. JEL Classification: G30, G32, G34 


\section{Introduction}

In the early years of the 21 st century, the high number of business collapses and corporate scandals, such as Enron and Worldcom, cost investors billions of dollars due to declines in share prices. Confidence in the securities markets was shaken. Consequently, governments and financial regulatory authorities in several countries introduced policies and regulations to protect shareholders' interests. For example, the Sarbanes-Oxley (SOX) Act of 2002 adds criminal penalties for corporate misdeeds of management. In Australia, the Corporate Governance Council (CGC) of the Australian Stock Exchange (ASX) has set guidelines for organisations and boards of directors to evaluate potential risks and implement proper risk management systems for their companies. Furthermore, the CGC of the ASX suggests forming a risk committee, with the majority of members being independent directors (ASX Corporate Governance Council, 2014).

The empirical evidence on the impact of investor protection on corporate risk-taking is mixed. For example, John, Litov and Yeung (2008) find a positive relationship between corporate risk-taking and investor protection, by defining investor protection based on the rule of law in a country, anti-director rights, and rating of accounting disclosure standards across different countries. In contrast, Bargeron, Lehn and Zutter (2010) find a relative decline in several measures of risk-taking in US firms compared with non-US firms, after the implementation of the SOX Act. However, the major limitation in these studies is that they compare the impact of investor protection on corporate risk-taking among the firms of different countries. For example, Bargeron et al. (2010) compare US firms with non-US firms; therefore, the relative decline in corporate risk-taking might be related to factors unique to US firms instead of the SOX Act. Similarly, the positive correlation between corporate risk-taking and investor protection in John et al. (2008), might also be a result of economic and other factors unique to those countries in the sample rather than the difference in investor protection. 
Therefore, the primary aim of this study is to empirically examine the association between the corporate risk-taking and the existence of a stand-alone risk committee. We argue that existence of a stand-alone risk committee enhances the quality of corporate governance which results in improved investor protection. Furthermore, we examine the impact of a standalone risk committee on firm value. We use the risk committee data of Australian firms to define the firms that have a stand-alone risk committee and those that have a joint audit and risk committee. To define corporate risk-taking, we use the level of investment in research and development, market return volatility, and the variability of accounting performance. As the primary purpose of setting up a stand-alone risk committee is to oversee the risk management framework of the firm and make recommendations on managing the risk of investment in projects, we therefore posit that firms with a stand-alone risk committee not only manage their risk properly but also avoid engaging in unnecessary risk prone activities which could result in a relative decline in their risk-taking measures. Furthermore, we expect that firms with a standalone risk committee have higher firm value since the existence of a stand-alone risk committee is presumed to lower the firm's overall risk of failure.

We advocate the existence of a stand-alone risk committee over a joint audit and risk committee for several reasons. Primarily, an audit committee is responsible for overseeing the financial reporting quality and issues relevant to financial reporting risk. However, some firms are engaged in a diversified range of risks, such as credit risk, foreign currency risk, strategic decision failure risk and risks relating to investments; these are just some among many risks which remain beyond the responsibility of the audit committee. Zaman (2001) casts doubt on the effectiveness of an audit committee on the risk management process and suggests that the skills required for risk management activities are distinct from the responsibilities of the audit committee. Finally, we understand that the approach to risk management varies between a stand-alone risk committee and a joint audit and risk committee. While the emphasis on risk 
assessment for a joint audit and risk committee is backward looking, a stand-alone risk committee considers a forward-looking approach.

Using the corporate governance data of Australian firms listed in the Australian Stock Exchange (ASX) in the years 2001 to 2013, we find that all three measures of risk-taking, i.e., the level of investment in research and development, market return volatility, and the variability of accounting performance, decline significantly for the firms that have a stand-alone risk committee compared with the firms that have a joint audit and risk committee. Our findings also suggest that firms with a stand-alone risk committee have higher firm values relative to the firms with a joint audit and risk committee. Finally, we use a propensity score matching technique and several other robustness tests and show that our main findings remain robust for the big size firms, firms with a higher number of independent directors on the risk committee, and for other firm-specific and corporate governance-related variables.

Our study contributes to the existing corporate governance literature by presenting new evidence that firms that are subject to the same economic conditions and regulations differ in their corporate risk-taking depending on the type of committee they use to manage risk. Therefore, in the absence of clear guidance on the regulation role of risk committees, our findings encourage firms to set up a stand-alone risk committee to not only reduce corporate risk-taking but also enhance firm value.

The remainder of this paper proceeds as follows. Section 2 reviews the existing literature and develops the relevant hypotheses, and Section 3 describes the sample and methodology. Section 4 presents the empirical results, and the last section concludes.

\section{Literature Review and Hypothesis development}

Risk-taking is an essential part of the business and the growth of a firm depends on operating at the right level of risk. The shareholders of a firm are justifiably concerned with 
whether management is taking risks based on shareholders' interests or based on their private interests (e.g. Eisenhardt, 1989). To alleviate the concerns of shareholders, governments and organizations introduce policies and rules to protect shareholders' interests and discourage management from taking unnecessary risks. In the US, for example, the SOX Act discourages directors from approving risky projects. Furthermore, the Act requires top management to certify their company's financial statements, and it imposes criminal liability for corporate misdeeds. In Australia, the ASX Corporate Governance Council recommends that an organization should evaluate potential risks before the inception of investment decisions and proposes that a risk committee is put in place (either as a stand-alone risk committee or part of the audit committee), comprised in the majority of independent directors (Principle 7 of ASX Corporate Governance Council, 2014).

Traditionally, it is the audit committee's role to measure and manage the overall risk profile of the company (e.g. Brown, Steen and Foreman, 2009). However, the audit committee might not have the required skills to effectively oversee firm risk, especially non-financial risk, i.e., operational, strategic, regulatory, and other risks (Daly and Bocchino, 2006; Zaman, 2001). Authorities in several countries have therefore suggested that companies have a stand-alone risk committee to manage the overall risk profile, with members having expertise in risk management activities (Financial Stability Board, 2013).

Despite numerous efforts to discourage firms from taking unnecessary risks, there is still debate whether policies and rules to protect investors would increase or decrease corporate risk-taking. One strand of literature suggests that managers avoid taking risky projects to protect their careers and personal benefits in firms and countries where investor protection is weak (e.g. Amihud and Lev, 1981; Hirshleifer and Thakor, 1992; Holmstrom and Costa, 1986). It follows that better investor protection and efficient monitoring mitigate the conservative risktaking approach of managers (Shleifer and Wolfenzon, 2002). In contrast, some studies argue 
that dominant shareholders have the authority to monitor managerial behaviour in low protected investor environments (Shleifer and Vishny, 1986; Shleifer and Wolfenzon, 2002); therefore, managers might not have the authority to avoid taking risky projects. However, in the presence of better investor protection, managers have less fear of expropriation and consequently, might have greater discretion to reduce risk.

Two recent studies (Bargeron et al., 2010; John et al., 2008) empirically examine the relationship between investor protection and corporate risk-taking. John et al. (2008) find support for the positive relationship between investor protection and corporate risk-taking by defining investor protection based on the rule of law in a country, anti-director rights, and rating of accounting disclosure standards across different countries. In contrast, Bargeron et al. (2010) find a significant decline in different measures of risk-taking in US firms compared to non-US firms after considering the impact of the SOX Act on US firms. They define investor protection based on the difference in capital expenditures, research and development expenses, the standard deviation of returns, etc. Therefore, the risk-taking measures in both studies are different from each other and not directly comparable. Furthermore, the findings of these studies might be a result of the difference in economic conditions and other factors because they do not examine and compare the relationship between investor protection and corporate risk-taking among the firms of the same country. Bargeron et al. (2010) mention in their paper that they cannot rule out the possibility that factors unique to the US firms might be related to their relative decline in risk-taking, when compared to the non-US firms, instead of the SOX Act. Thus, it would be useful to examine the corporate risk-taking of firms from the same country, Australia ${ }^{1}$, and compare those that have a stand-alone risk committee with those that have a joint audit and risk committee.

\footnotetext{
${ }^{1}$ We do not include the firms that do not provide information whether they have a risk committee or joint audit and risk committee in our main analysis because it is possible that those firms do not provide details about their
} 
There are only a few studies that examine the impact of stand-alone risk committee on corporate governance using data from Australia or Malaysia. Yatim (2010) finds that Malaysian firms with a higher number of independent directors on the board are likely to set up an independent or stand-alone risk committee to show their commitment to minimizing financial, operational and reputational risks. Subramaniam, McManus and Zhang (2009) identify that stand-alone risk committees tend to exist in Australian companies with larger boards and an independent board chairperson, and in companies with higher financial reporting risk and lower organisational complexity. However, the major limitation of the Subramaniam et al. (2009) study is that only 22 of their 200 sample companies have a stand-alone risk committee which raises the concern of generalizability of findings. Furthermore, the Yatim (2010) and Subramaniam et al. (2009) studies only examine firm characteristics and board factors associated with the establishment of the stand-alone risk committee. In a recent paper, $\mathrm{Ng}$, Chong and Ismail (2012) examine the relationship between risk management committee and the underwriting risk of insurance companies in Malaysia and find that risk-taking is negatively associated with risk committee size and board independence. However, there are some limitations to their study. First, the risk management committee is compulsory for all the insurance firms in their sample. Second, they use underwriting risk that is limited to only underwriting companies. Third, the total number of observations in their sample is only 329. In summary, there is not one study that tests the impact of stand-alone risk committees on the corporate risk-taking of non-insurance firms.

Overall, the literature offers both positive and negative relationships between investor protection and corporate risk-taking. However, prior studies are limited in that they do not compare the relationship between investor protection and corporate risk-taking among firms

committees. However, we compare the firms with stand-alone risk committees with the firms without stand-alone committees in the robustness tests, and our results remain robust. 
facing the same economic conditions and regulations i.e. firms from one country. Therefore, using only Australian data, we fill the gap in the literature by comparing the risk-taking of firms having a stand-alone risk committee with that of firms having a joint audit and risk committee. The purpose of the stand-alone risk committee is to effectively manage the overall risk profile of the company which enhances the quality of corporate governance; therefore, we expect relatively higher investor protection in firms with a stand-alone risk committee compared to firms with a joint audit and risk committee. Furthermore, we expect a decline in risk-taking measures for firms with a stand-alone risk committee, as those firms are required to disclose additional risk-relevant information. Based on the above discussion we develop the following hypothesis:

$H_{1}$ : Risk-taking propensity is lower for firms with a stand-alone risk committee.

We then examine the impact of risk committee on firm performance, as the existence of a stand-alone risk committee is presumed to lower the firm's overall risk of failure and, thus, increase firm performance. In fact, a large body of accounting and finance literature suggests that an improvement in risk management activities improves firm performance, especially among firms with a history of good corporate governance (e.g. Aebi, Sabato and Schmid, 2012; Gordon, Loeb and Tseng, 2009). Furthermore, the firms with an efficient risk management system are likely to avoid unnecessary risks, i.e. the risk for which the firm does not expect to receive compensation (e.g., Nocco and Stulz, 2006).

Therefore, we suggest that having a stand-alone risk committee increases the value of a firm, as it is regarded as an indicator of good corporate governance and efficient risk management of the firm's risk-related activities. Thus, our second hypothesis is:

$\mathrm{H}_{2}$ : Firm performance improves in the presence of a stand-alone risk committee. 


\section{Research Design}

\subsection{Sample Selection}

We collect risk committee data of Australian firms from the Securities Industry Research Centre of Asia-Pacific (SIRCA) and monthly returns and financial accounting data from DataStream International. We limit our sample period from 2001 to 2013 because SIRCA does not provide risk committee data prior to 2001. Our sample from SIRCA provides us with 13,488 firm-year observations on risk committee. We match risk committee firm-year observations with financial accounting data which results in 7,530 firm-year observations where each of the matched firm-years has either risk committee or financial accounting data. Following the literature (Lobo, 2017), we exclude financial institutions and remove 811 firmyear observations from our sample. We then delete 4,818 firm-year observations which have no operational risk committees (neither a separate stand-alone risk committee nor a joint audit and risk committees), from either the SIRCA or DataStream data, which leaves a final sample of 1,901 firm-year observations. The final sample includes a combination of stand-alone risk committee $(\mathrm{N}=241)$ and joint audit and risk committees $(\mathrm{N}=1700)$. Finally, we winsorize all the continuous variables at the $1^{\text {st }}$ and $99^{\text {th }}$ percentiles to reduce the impact of outliers.

Table 1 about here

\subsection{Empirical Model}

We estimate the following model to test the risk-taking of the firms when a stand-alone risk committee is operational (hypothesis 1).

$$
\begin{aligned}
& R_{I S K_{i t+1}}=\partial_{0}+\partial_{1} R C+\partial_{2} L O G S I Z E+\partial_{3} M T B V+\partial_{4} L E V+\partial_{5} C A P E X+\partial_{6} \Delta S A L E S+ \\
& \partial_{7} L O G A G E+\partial_{8} P M+\partial_{9} I M R+\sum \partial_{i} Y E A R+\sum \partial_{j} I N D U S T R Y+\varepsilon \ldots \ldots \ldots \ldots(1)
\end{aligned}
$$


RISK is a proxy for corporate risk-taking measure for each firm. We use three different measures of corporate risk-taking: the level of research and development $(R \& D / T A)$ as an investment risk measure, the standard deviation of returns $\sigma(M R E T)$ as a market-based measure, and the standard deviation of return on assets $\sigma(R O A)$ as an accounting measure. We estimate $R \& D$ as the research and development expenditure scaled by total assets. Bhagat and Welch (1995) suggest that the benefits of $R \& D$ investment are uncertain and have a lower probability of success which reflects risk-taking propensity on long-term investment. Following the literature (Gomez-Mejia, Campbell, Martin, Hoskisson, Makri and Sirmon, 2014), we set R\&D equal to zero for missing values. We measure $\sigma(M R E T)$ as the annual standard deviation of monthly stock returns in a year. The $\sigma(M R E T)$ is a conventional measure of corporate equity risk. A high value of $\sigma(M R E T)$ denotes more dispersion and, thus, high levels of risk (Bargeron et al., 2010). Finally, we compute $\sigma(R O A)$ as the standard deviation of the income before tax and extraordinary items, scaled by total assets, over the prior three years. The $\sigma(R O A)$ is widely used as an indicator of risk-taking measure (Habib and Hasan, 2017; Li, Griffin, Yue and Zhao, 2013; Nakano and Nguyen, 2012; Wright, Kroll, Krug and Pettus, 2007), and it captures the overall risk taken by the firm. We use risk measures in one-yearahead values to capture the impact of an operational stand-alone risk committee.

Our main variable of interest on the right side of equation (1), $R C\left(\partial_{1}\right)$ is equal to 1 if a stand-alone risk committee is operational, otherwise 0 . We expect the coefficient $\partial_{1}$ to be negative since we hypothesize that stand-alone risk committee reduces the corporate risktaking. We also include the firm-specific variables on the right side of equation (1) that are suggested in the literature to have an impact on corporate risk-taking. Firm size (LOGSIZE) is a natural logarithm of total assets. The large firms are less likely to engage in high-risk investments and have more risk tolerance even if a risky investment initiates. We expect a negative association between LOGSIZE and RISK measures (Bargeron et al., 2010). Firms with 
higher leverage ( $L E V)$ might constrain risk-taking propensity. Leverage $(L E V)$ is defined as total debt to total assets as a proxy of financial resources. We expect a negative association between $L E V$ and different RISK measures because firms with higher debt are more likely to be monitored by creditors, which results in lower risk (Li et al., 2013). Firms with high growth opportunities $(M T B V)$, measured as the ratio of market value of equity to book value of equity, are likely to choose riskier investments. We expect a positive association between $M T B V$ and different measures of RISK (Laeven and Levine, 2009). Rogers (2002) shows that corporate risk-taking propensity is higher when capital expenditure $(C A P E X)$ increases. We expect a positive association between CAPEX and RISK measures. We consider two proxies (SALESCHANGE and $P M$ ) to capture the variability and changes in sales. Sales growth is the change in sales compared to the previous year scaled by total assets. We expect a positive association between SALESCHANGE and different measures of RISK. A firm with higher sales change generates more cash flow and net income which leads to increased market return. Thus, investment is more rewarding when sales growth is higher (Anthony and Ramesh, 1992). Profit margin $(P M)$ is the profitability of firm measured by the income before tax and extraordinary items, scaled by sales. Zahra (2005) posits that older firms tend to invest in new or uncertain projects to retain market leadership over the company's life cycle. Therefore, due to their more stable financial position, firms that have been operating for a long time are more likely to choose risky investments compared with younger firms. Therefore, we expect a positive association between firm age (LOGAGE) and RISK measures. We calculate the Inverse Mills Ratio (IMR) following equation (3) which is explained in section 3.3. Our regression analysis considers any unobservable effect of operating year (YEAR) and industry (INDUSTRY). We cluster the standard errors at the firm (INDUSTRY) and time (YEAR) levels to control for crosssectional and time-series dependence, respectively (Petersen, 2009). 
To test the impact of a stand-alone risk committee on firm value (hypothesis 2), we estimate the following regression model:

$F V A L_{i t}=\gamma_{0}+\gamma_{1} B O D S I Z E+\gamma_{2} B O D I N D+\gamma_{3} B I G 4+\gamma_{4} L O G S I Z E+\gamma_{5} L E V+$ $\gamma_{6} M T B V+\gamma_{7} C A P E X P+\gamma_{8} S A L E C H A N G E+\gamma_{9} L O G A G E+\gamma_{10} R C+\sum \gamma_{i} Y E A R+$ $\sum \gamma_{j} I N D U S T R Y+\varepsilon$

Our main variable of interest on the right side of equation (2) is $R C\left(\gamma_{10}\right)$. We expect the coefficient $\gamma_{10}$ to be positive because we hypothesize that stand-alone risk committee increases the value of the firm as it is regarded as an indicator of good corporate governance.

Following the literature (e.g. McConnell and Servaes, 1990; Villalonga and Amit, 2006), we use Tobin's Q (TOBIN'SQ) as a proxy for firm value (FVAL). Tobin's Q is measured as a ratio of the firm's market value to total assets. Following Baxter, Bedard, Hoitash and Yezegel (2013), we use Return on Assets (ROA) as an additional proxy for firm value that captures the accounting performance, ROA, measured as the ratio of income before extraordinary items divided by total assets. Finally, we include a set of corporate governance variables (BODSIZE, BODIND and BIG4) on the right side of the equation (2) which are identified in the literature to enhance firm value (e.g. Carter, Simkins and Simpson, 2003). BODSIZE is the size of board directorship measured by the natural logarithm of total board size; $B O D I N D$ is the representation of independent directors in the board measured as a ratio of total number of independent directors to total board size; BIG4 is audit quality, assigned as a value of 1 if the firm is audited by a big- 4 auditor, otherwise 0 . Similar to equation 1 , we add a set of firm-specific variables (LOGSIZE, LOGAGE, LEV, MTBV, CAPEX and SALESCHANGE) on the right side of equation 2. We cluster the standard errors at the firm (INDUSTRY) and time (YEAR) levels to control for cross-sectional and time-series dependence, respectively (Petersen, 2009). 


\subsection{Self-selection of risk committee and corporate risk-taking}

The ordinary least squares regression estimates the determinants of corporate risktaking as a function of stand-alone risk committee and other control variables, where the choice of stand-alone risk committee is random. However, firms with specific characteristics are more likely to establish a stand-alone risk committee, i.e., big size firms, firms with independent directors, etc. Therefore, we apply the Heckman two-stage test to address the self-selection problem of the stand-alone risk committee, as the existence of a stand-alone committee might be a non-random choice. We estimate the following PROBIT model in the first stage of regression analysis:

$$
\begin{aligned}
& \operatorname{Pr}(R C)_{i t}=\mu_{0}+\mu_{1} \text { BODSIZE }+\mu_{2} \text { BODIND }+\mu_{3} \text { BIG } 4+\mu_{4} \text { LOGSIZE }+\mu_{5} L E V+ \\
& \sum \mu_{6} Y E A R+\sum \mu_{7} I N D U S T R Y+\varepsilon \ldots \ldots \ldots \ldots \ldots \ldots \ldots \ldots \ldots
\end{aligned}
$$

We expect a positive association between $R C$ and a set of corporate governance variables (BODSIZE, BODIND, BIG4), as firms with large board size (BODSIZE), higher number of independent directors (BODIND) and large auditors (BIG4), are more likely to set up a stand-alone risk committee (e.g. Subramaniam et al., 2009; Yatim, 2010). Furthermore, we expect a positive association between $\mathrm{RC}$ and big size firms (LOGSIZE) because big size firms are capable of delegating separate responsibilities to the board of directors and are more likely to set up a stand-alone risk committee (Subramaniam et al., 2009). We also expect a positive association between $R C$ and firms with higher leverage ( $L E V$ ) because firms with higher leverage $(L E V)$ are more likely to set up a stand-alone committee as higher leverage requires more internal monitoring (Hines and Peters, 2015). Finally, we control for any unobservable effect of operating year (YEAR) and industry (INDUSTRY) which might affect the existence of a stand-alone risk committee. We cluster the standard errors at the firm 
(INDUSTRY) and time (YEAR) levels to control for cross-sectional and time-series dependence, respectively (Petersen, 2009).

\section{Results}

\subsection{Descriptive statistics}

Table 2 reports the descriptive statistics and correlation analysis of our main variables. Panel A of Table 2 shows that almost 13\% of the firm-year observations have a stand-alone risk committee and the average risk measures, $R \& D / T A, \sigma(M R E T)$, and $\sigma(R O A)$, are 0.016, 0.172 and 0.137 , respectively. The mean value of TOBIN'SQ and Return on Assets (ROA) is 0.709 and $6.4 \%$, respectively. Furthermore, the mean value of leverage ( $L E V)$ and capital expenditure $(C A P E X)$ is 0.106 and 0.089 , respectively. The average number of directors (BODSIZE) on the board is almost 6, of which 4 are independent directors (BODIND). Almost $60 \%$ of the firm-year observations are audited by large auditors (BIG4).

Table 2 about here

\subsection{Mean difference test}

Panel B of Table 2 reports the descriptive statistics of the firms with a stand-alone risk committee $(R C=1)$ and those with a joint audit and risk committee $(R C=0)$. It also provides the mean difference between the firms with a stand-alone risk committee and those with a joint audit and risk committee. There are 241 firm-year observations for stand-alone risk committee out of 1901 total observations. The firms with a stand-alone risk committee have relatively lower variability on all three risk measures $(R \& D / T, \sigma(M R E T) \sigma(R O A))$, compared with the firms with a joint audit and risk committee. Both the proxies of firm value (TOBIN'SQ and $R O A$ ) are higher in the presence of a stand-alone risk committee. Furthermore, the firms with a stand-alone risk committee are relatively older and more leveraged compared to the firms 
with a joint audit and risk committee. These findings are not surprising as the corporate governance literature indicates that mature and visible firms tend to practice better corporate governance. Finally, the firms with a stand-alone risk committee have a relatively large board size and a higher number of independent directors on the board compared to the firms with a joint audit and risk committee. All the results are statistically significant at the 5\% level.

\subsection{Correlation Analysis}

Panel $\mathrm{C}$ of Table 2 reports the results of bivariate correlation analysis. The firms with a stand-alone risk committee have a negative correlation with all the measures of corporate risk-taking which indicates that a stand-alone risk committee reduces the propensity of risktaking. Both the proxies of firm value (TOBIN'SQ and ROA) shows a positive correlation $(\mathrm{r}=0.19,0.07 ; \mathrm{p}<0.001)$ with the existence of a stand-alone risk committee $(R C)$. All the measures of risk-taking (RISK) and firm value (TOBIN'SQ and ROA) show consistently positive correlations that are statistically significant at the $1 \%$ level. There is a positive correlation $(\mathrm{r}=0.24, \mathrm{p}<0.001)$ between $R C$ and board size $(B O D S I Z E)$ which indicates that the firms with a stand-alone risk committee have a relatively large board size and a higher number of independent directors on the board $(\mathrm{r}=0.20, \mathrm{p}<0.001)$. Furthermore, there is a positive correlation $(\mathrm{r}=0.07, \mathrm{p}<0.05)$ between firms with a stand-alone risk committee and large auditors $(B I G 4)$ which indicate that firms with a stand-alone risk committee are being audited by the large auditors. Finally, there is a strong positive correlation $(\mathrm{r}=0.90)$ between board size (BODSIZE) and board independence (BODIND) which raise concerns of multicollinearity. We will discuss our approach addressing the multicollinearity concerns in section 4.4.

\subsection{Multivariate Regression Analysis}

Table 3 reports the regression results for equation (1), where we regress the measures of risk-taking $(R I S K)$ on several variables that might have an impact on corporate risk-taking. 
Recall from section 3.2 that we employ three different risk-taking measures, $(R \& D / T A)_{t+1}$, $\sigma(M R E T)_{t+1}$ and $\sigma(R O A)_{t+1}$, as a dependent variable to capture the impact of a stand-alone risk committee on corporate risk-taking. We also present the findings of equation (3) which was developed to control for self-selection biases of the existence of stand-alone risk committee. Column 2 shows the regression results for self-selection biases (equation 3). We estimate the Inverse-Mill Ratio (IMR) based on equation 3 and include it in equation (1) to eliminate any self-selection bias.

Table 3 about here

Columns $3-5$ of Table 3 present the coefficients of risk-taking measures $\left((R \& D / T A)_{t+1}\right.$, $\sigma(M R E T)_{t+1}$ and $\left.\sigma(R O A)_{t+1}\right)$, without including the control variables. We find that all measures of risk-taking decline significantly for the firms with a stand-alone risk committee compared to firms with a joint audit and risk committee. For example, the coefficients for $(R \& D / T A)_{t+1}$, $\sigma(M R E T)_{t+1}$ and $\sigma(R O A)_{t+1}$ are $-0.018 * * *,-0.033 * * *$ and $-0.061 * * *$, respectively, which indicates that the firms with a stand-alone risk committee are relatively more risk-averse compared to the firms with a joint audit and risk committee.

Empirical evidence indicates that firm-specific characteristics and corporate governance settings influence corporate risk-taking (John et al., 2008; Nguyen, 2011). Columns 6-8 of Table 3 include the firm-specific and corporate governance-related variables and also the Inverse-Mill ratio $(I M R)$ to eliminate self-selection bias. ${ }^{2}$ Consistent with our main results, in columns $3-5$ of Table 3 , we find that all the risk-taking measures $\left((R \& D / T A)_{t+1}\right.$, $\sigma(M R E T)_{t+1}$ and $\left.\sigma(R O A)_{t+1}\right)$ have a significant negative association with $R C$ even after

\footnotetext{
2 To avoid the multicollinearity concerns, we exclude both the highly correlated variables (BODSIZE and $B O D I N D)$, one at a time to calculate the inverse mill ratio. The statistical significance of the results for equation 1 remains unchanged. The details are explained in the latter part of this sub-section.
} 
including the firm-specific and corporate governance-related variables. This indicates that the firms with a stand-alone risk committee have a relatively lower risk-taking propensity, consistent with the literature (e.g. Bargeron et al., 2010). Furthermore, we find a significant negative association between risk-taking measures and firm size (LOGSIZE), leverage (LEV) and profit margin $(P M)$, which is also consistent with the literature (Subramaniam et al., 2009; Yatim, 2010). The adjusted- $\mathrm{R}^{2}$ ranges from $18.16 \%$ to $29.66 \%$ which indicates a strong predictability of the regression models.

Table 4 about here

To examine the impact of a stand-alone risk committee $(R C)$ on the firm value (hypothesis 2), we estimate equation (2) and report the results in Table 4. As discussed earlier, we use two different proxies for firm value; TOBIN'SQ and ROA. The coefficient of a standalone risk committee $(R C)$ is $0.101(t$-stat $=7.54)$ and $0.034(t$-stat $=3.94)$ for TOBIN'SQ and $R O A$, respectively which shows that the firms with a stand-alone risk committee have relatively higher firm value. Among the control variables, the coefficients for firm size (LOGSIZE), and leverage $(L E V)$ are positive and statistically significant at least at $10 \%$ level. Firms with a larger board (BODSIZE) show a negative association with both the proxies of firm value (TOBIN'SQ and $R O A$ ) and the coefficients are statistically significant at the 5\% level. The adjusted Rsquares of the models range between $12.67 \%$ to $17.94 \%$. To detect multicollinearity, we use the variance inflation factor $(V I F)$ for all the independent variables. All the VIF values are well below the commonly used cut-off point of 10 which indicates no signs of multicollinearity.

\subsection{Additional tests}

a. Propensity Score Matching (PSM)

We understand that the existence of a stand-alone risk committee might be a nonrandom choice; therefore, our results might be driven by the systematic differences in firm 
characteristics between the firms with a stand-alone risk committee and those with a joint audit and risk committee. Rosenbaum and Rubin (1983) suggest matching the 'treatment group' to a 'control group' to test whether there is a statistically significant difference for the firmspecific variables between the firms in each group.

Using PSM, we estimate the difference between the corporate risk-taking of the firms with a stand-alone risk committee and the firms with a joint audit and risk committee. We use a stand-alone risk committee as a treatment group. The set of covariates for the matching estimates are the firm size (LOGSIZE), large auditor (BIG4), leverage (LEV), firm age $(L O G A G E)$ and profit margin $(P M)$. We use nearest neighbour techniques to perform the PSM model.

Table 5 about here

We rerun equations (1) and (2) to test our hypotheses 1 and 2 and report the results in Table 5. We find that all the measures of corporate risk-taking decline significantly for the firms that have a stand-alone risk committee compared with those that have a joint audit and risk committee. Furthermore, we find that the firms with a stand-alone risk committee have relatively higher firm value. All the results are statistically significant at least at the $5 \%$ level. Overall, our results in Table 5 based on PSM analysis are consistent with our main results and show a negative (positive) relationship between the existence of a separate risk committee and firm risk-taking propensity (firm value).

\section{b. Risk committee independence and risk-taking propensity}

A large body of corporate governance literature shows that a higher number of independent directors on the board enhances firm performance (e.g. Rosenstein and Wyatt, 1990). Furthermore, a higher number of independent directors on the board is also positively associated with the existence of a risk committee (Yatim, 2010). Therefore, we rerun equation 
1 to test the role of a stand-alone risk committee with a higher proportion of independent directors on the board and report the results in Table 6 . The results indicate that the firms with a higher proportion of independent directors on the board in stand-alone risk committees are less likely to engage in risk-taking activities. For example, the association between independent risk committee (\%RC_independence) and $\sigma(R \& D)_{t+1}$ is negative and statistically significant (coefficient $=-0.003^{*}, t$-stat $=-1.71$ ), the association between independent risk committee and $\sigma(M R E T)_{t+1}$ is also negative and statistically significant (coefficient $=-0.019 * *, t$-stat $\left.=-2.04\right)$, and the association between independent risk committee and $\sigma(R O A)_{t+1}$ is also negative and statistically significant (coefficient $=-0.057^{* *}, t$-stat $=-2.74$ ). The adjusted R-square ranges between $15.26 \%$ and $35.01 \%$.

Table 6 about here

\section{c. Impact of Missing $R \& D$ on our findings}

The accounting and finance literature often interprets the missing $R \& D$ values as firms with zero R\&D activities; however, in a recent paper, Koh and Reeb (2015) find that firms with missing $R \& D$ values are unlike firms with zero $R \& D$ activities. Therefore, we reanalyse equation 1 after excluding the firm-year observation with zero $R \& D$ values. Results are tabulated in Table 6 . We have a total of 348 firm-year observations with non-zero R\&D values. The empirical evidence shows a significant negative association between $R C$ (coefficient $=-0.069 * *, t$-stat $=-2.11)$ and $\sigma(R \& D)_{t+1}$; whereas, a positive association is found between $\mathrm{RC}$ (coefficient $=0.027^{*}$ and $0.031, t$-stat $=1.79$ and 2.29 ) and firm value. Overall, these results are consistent with our main findings.

\section{d. Impact of firm size on risk committee formation}


Arguably, setting up a stand-alone risk committee requires the unique expertise of the directors; therefore, maintaining a separate risk committee might require additional costs. Consequently, the chances of setting up a stand-alone risk committee increase with firm size. Interestingly, Christensen, Kent, Routledge and Stewart (2015) show a significant shift by small and large companies during 2003 to comply with the Australian Securities Exchange Limited governance recommendations. We split the sample based on the median firm size (LOGSIZE) into small (below median) and big size (above median) firms and assign a value of 1 to the big size firms, otherwise 0 . Using equation 1 , we find that that the big size firms with a stand-alone risk committee have less propensity to engage in risk-taking activities. For example, the coefficients for $(R \& D / T A), \sigma(M R E T)$ and $\sigma(R O A)$ are $-0.008,-0.013$ and -0.029 , respectively, and all are statistically significant. The results are consistent with the notion of firm life cycle theory which indicates that big size firms are mostly at the mature stage of the firm life cycle and therefore have stable operating incomes and cash flows, which might discourage aggressive risk-taking.

\section{Table 7 about here}

e. Comparing firms with non-risk committee and stand-alone risk committees

Finally, we understand that the firms without an operational risk committee, either a standalone or joint audit and risk committee, also engage in risk-taking or risk-mitigating activities. Therefore, in this section, using a propensity score matching approach we compare the risktaking of firms with stand-alone risk committee versus firms with no risk committee (neither a stand-alone nor a joint audit and risk committee). We report the results in Table 7 . We use a dichotomous variable $(R C)$ to test the effect of stand-alone risk committees. We assign a value of 1 to the firms with a stand-alone risk committee and a value of 0 to the firms with no risk committee. We use each of the risk-taking proxies $\left((R \& D / T A)_{t+1}, \sigma(M R E T)_{t+1} \& \sigma(R O A)_{t+1}\right)$ 
separately as a dependent variable and $R C$ as an independent variable. Columns 5-7 of Table 7 show that $R C$ has a consistently negative association with all the risk-taking proxies, consistent with our findings in Section 4.4.

\section{f. Risk taking and other corporate governance characteristics}

To examine whether our primary results of corporate risk-taking based on equation (1) are sensitive to different model specifications, we perform an additional sensitivity test that incorporates different corporate governance characteristics such as board size, board independence and audit quality. Extant corporate governance literature suggests a negative association between risk-taking and board size (e.g., Nakano and Nguyen, 2012). Jensen (1993) points out that when a board gets larger in size, higher coordination and communication costs make the board less likely to function effectively. In contrast, a smaller board is expected to act more consistently with the shareholders' interest by encouraging value-increasing policies, which are possibly riskier than managers would have chosen otherwise (Lee and Lee, 2009; Yermack, 1996). Conventionally, a firm with a higher number of independent directors on board is less likely to be influenced by the CEO; thus, might be relatively less risk-averse relative to a firm with a lower number of independent directors on the board. Finally, a firm with high-risk project relative to a firm with low-risk project might prefer to be audited by nonbig4 audit firms to avoid highlighting audit risk. We measure BODSIZE as the natural logarithm of a total number of board members; BODIND as the proportion of independent directors on a board and BIG4 as a dichotomous variable assigned a value of 1 if the auditor is a BIG4 firm, otherwise 0. We add BODSIZE, BODIND and BIG4 in equation (1) and re-run the regression.

We still find a negative and statistically significant association between $R C$ (coefficient $=-0.006,-0.015,-0.021 ; t$-stat $=-1.93,-1.74,-3.14)$ and all the risk-taking proxies 
$\left((R \& D / T A)_{t+1}, \quad \sigma(M R E T)_{t+1} \& \sigma(R O A)_{t+1}\right) .{ }^{3}$ BODIND shows negative and statistically significant association (coefficient $=-0.002,-0.004,-0.003 ; t$-stat $=-3.87,-1.89,-3.81$ ) with all the risk-taking proxies. Findings of other control variables are consistent with our primary results.

\section{g. Do the risk committee attributes affect risk-taking and firm value?}

As an additional robustness test, we consider other risk committee characteristics that might affect corporate risk-taking and firm value, such as financial expertise, tenure and busyness. Minton, Taillard and Williamson (2014) posit that financial experts can identify risks that are beneficial to shareholders and encourage management to take those risks. Following Güner, Malmendier and Tate (2008), we define financial expertise (FINEXP) as a continuous variable which is measured as the total number of directors with previous experience and expertise as $\mathrm{CFO}, \mathrm{CEO}$, or other financial executive positions or holding professional affiliation as CFA, FCA, FCMA, CPA and Ph.D., etc. Anecdotally, the risk perspective of the firm changes with the firm-specific experience (tenure) of a director as a director with longer tenure might be able to reduce corporate risk-taking. We use an average number of years of tenure of the risk committee members (RISKTEN). We also use the busyness of a risk committee since a busy committee might overlook the monitoring vigilance which might lead to selecting risky projects. We use an average number of directorial position held by the risk committee members (RISKBUSY). We estimate the following regression models:

$$
\begin{aligned}
& R_{I S K_{i t+1}}=\partial_{0}+\partial_{1} R C+\partial_{2} \text { LOGSIZE }+\partial_{3} M T B V+\partial_{4} L E V+\partial_{5} \text { CAPEX }+ \\
& \partial_{6} \text { SSALES }+\partial_{7} \text { LOGAGE }+\partial_{8} \text { PM }+\partial_{9} \text { FINEXP }+\partial_{10} \text { RISKTEN }+\partial_{11} \text { RISKBUSY }+ \\
& \partial_{12} I M R+\sum \partial_{i} Y E A R+\sum \partial_{j} I N D U S T R Y+\varepsilon \ldots \ldots \ldots \ldots(4)
\end{aligned}
$$

\footnotetext{
${ }^{3}$ We do not tabulate these results for the sake of brevity.
} 


$$
\begin{aligned}
& \text { FVAL } L_{i t}=\gamma_{0}+\gamma_{1} \text { BODSIZE }+\gamma_{2} \text { BODIND }+\gamma_{3} \text { BIG } 4+\gamma_{4} L O G S I Z E+\gamma_{5} L E V+ \\
& \gamma_{6} \text { MTBV }+\gamma_{7} \text { CAPEXP }+\gamma_{8} \text { SALECHANGE }+\gamma_{9} L O G A G E+\partial_{10} \text { FINEXP }+ \\
& \partial_{11} \text { RISKTEN }+\partial_{12} \text { RISKBUSY }+\gamma_{13} R C+\sum \gamma_{i} Y E A R+\sum \gamma_{j} I N D U S T R Y+\varepsilon \ldots \ldots
\end{aligned}
$$

Table 8 about here

Table 8 reports the result of equation (4) and (5). Columns $2-4$ show the impact of a stand-alone risk committee on firm risk-taking (Equation 4). Consistent with our main results, we find that all the measure of risk-taking decline significantly for the firms with a stand-alone risk committee. Among the other variable of interest related to risk committee characteristics, RISKTEN shows a negative and statistical significant association $($ coefficient $=-0.002,-0.002$, $-0.007 ; t$-stat $=-1.69,-3.71,-4.52)$ with all the risk-taking proxies $\left[(R \& D / T A)_{t+1}, \sigma(M R E T)_{t+1}\right.$ and $\sigma(R O A)_{t+1}$. Columns 5 and 6 report the impact of a stand-alone risk committee on firm value (Equation 5). We find a positive and statistically significant association between a standalone risk committee (coefficient $=0.024,0.009 ; t$-stat $=2.38,4.28)$ and both the measures of firm value (TOBIN'S $Q$ and $R O A$ ). None of the variables representing the characteristics (financial expertise, tenure and busyness) of risk committee show any significant impact on firm value. In sum, all the robustness tests further confirm our main findings that existence of a stand-alone risk committee not only reduces the firm risk-taking but also enhances the firm value.

\section{Conclusion}

In this paper, we examined the impact of stand-alone risk committee on corporate risktaking and firm value. The primary objective of a stand-alone risk committee is to effectively manage the risk profile of the company and its members are experts in risk management. Therefore, we expected a relative decline in the risk-taking measure for the firms with standalone risk committees as those firms are required to disclose additional risk-relevant 
information. Furthermore, we suggested that the existence of a stand-alone risk committee would increase the value of the firm, as it is regarded as an indicator of good corporate governance in the effective management of the firm's risk-related activities.

We empirically examined our hypotheses using data for the years 2001-2013 from publicly trading Australian firms which had either a stand-alone risk committee or a joint audit and risk committee. We used three different measures to define corporate risk-taking, i.e., the level of research and development $(R \& D / T A)$ as an investment risk measure, the standard deviation of returns $\sigma(M R E T)$ as a market-based measure, and the standard deviation of return on assets $\sigma(R O A)$ as an accounting measure. We document a significant negative relationship between corporate risk-taking and the existence of a stand-alone risk committee. Furthermore, we find that the firms with a stand-alone risk committee have a relatively higher firm values. Therefore, these results support our hypothesis that a stand-alone risk committee not only reduces firm corporate risk-taking but also enhances firm value. Our results are robust to controls for firmspecific characteristics, corporate governance-related variables and use of a Propensity Score Matching technique.

Our study contributes to the existing corporate governance literature in at least two ways. First, it presents the new evidence that firms that are subject to the same economic conditions and regulations differ in their corporate risk-taking based on their choice of the committee to manage firm risk. Second, our study is the first to empirically examine the impact of standalone risk committee on corporate risk-taking and firm value. Our study is subject to limitations, and the primary limitation is that we keep our analysis limited to Australian firms because of the unavailability of data for other countries. Therefore, we hope that future research can further explore the relationship between corporate risk-taking and stand-alone risk committee in international settings. 


\section{References}

Aebi, V., Sabato, G., Schmid, M., 2012. Risk management, corporate governance, and bank performance in the financial crisis. Journal of Banking \& Finance 36, 3213-3226.

Amihud, Y., Lev, B., 1981. Risk reduction as a managerial motive for conglomerate mergers. The Bell Journal of Economics, 605-617.

Anthony, J.H., Ramesh, K., 1992. Association between accounting performance measures and stock prices: A test of the life cycle hypothesis. Journal of Accounting and Economics $15,203-227$.

Bargeron, L.L., Lehn, K.M., Zutter, C.J., 2010. Sarbanes-Oxley and corporate risk-taking. Journal of Accounting and Economics 49, 34-52.

Baxter, R., Bedard, J.C., Hoitash, R., Yezegel, A., 2013. Enterprise risk management program quality: Determinants, value relevance, and the financial crisis. Contemporary Accounting Research 30, 1264-1295.

Bhagat, S., Welch, I., 1995. Corporate research \& development investments international comparisons. Journal of Accounting and Economics 19, 443-470.

Board, F.S., 2013. Thematic review on risk governance, Peer Review Report.

Brown, I., Steen, A., Foreman, J., 2009. Risk management in corporate governance: A review and proposal. Corporate Governance: An International Review 17, 546-558.

Carter, D.A., Simkins, B.J., Simpson, W.G., 2003. Corporate governance, board diversity, and firm value. Financial review 38, 33-53.

Christensen, J., Kent, P., Routledge, J., Stewart, J., 2015. Do corporate governance recommendations improve the performance and accountability of small listed companies? Accounting \& Finance 55, 133-164.

Council, A.C.G., 2014. Corporate governance principles and recommendations. ASX Corporate Governance Council Sydney.

Daly, K., Bocchino, C., 2006. Where is the risk. Audit Roundup, Directorship, available at: www. directorship. com.

Eisenhardt, K.M., 1989. Agency theory: An assessment and review. Academy of Management Review 14, 57-74.

Gomez-Mejia, L.R., Campbell, J.T., Martin, G., Hoskisson, R.E., Makri, M., Sirmon, D.G., 2014. Socioemotional wealth as a mixed gamble: Revisiting family firm R\&D investments with the behavioral agency model. Entrepreneurship Theory and Practice $38,1351-1374$.

Gordon, L.A., Loeb, M.P., Tseng, C.-Y., 2009. Enterprise risk management and firm performance: A contingency perspective. Journal of Accounting and Public Policy 28, 301-327. 
Güner, A.B., Malmendier, U., Tate, G., 2008. Financial expertise of directors. Journal of Financial Economics 88, 323-354.

Habib, A., Hasan, M.M., 2017. Firm life cycle, corporate risk-taking and investor sentiment. Accounting and Finance 57, 465-497.

Hines, C.S., Peters, G.F., 2015. Voluntary risk management committee formation: Determinants and short-term outcomes. Journal of Accounting and Public Policy 34, 267-290.

Hirshleifer, D., Thakor, A.V., 1992. Managerial conservatism, project choice, and debt. Review of Financial Studies 5, 437-470.

Holmstrom, B., Costa, J.R.I., 1986. Managerial incentives and capital management. The Quarterly Journal of Economics 101, 835-860.

Jensen, M.C., 1993. The modern industrial revolution, exit, and the failure of internal control systems. the Journal of Finance 48, 831-880.

John, K., Litov, L., Yeung, B., 2008. Corporate governance and risk-taking. The Journal of Finance 63, 1679-1728.

Koh, P.-S., Reeb, D.M., 2015. Missing R\&D. Journal of Accounting and Economics 60, 7394.

Laeven, L., Levine, R., 2009. Bank governance, regulation and risk taking. Journal of Financial Economics 93, 259-275.

Lee, K.-W., Lee, C.-F., 2009. Cash holdings, corporate governance structure and firm valuation. Review of Pacific Basin Financial Markets and Policies 12, 475-508.

Li, K., Griffin, D., Yue, H., Zhao, L., 2013. How does culture influence corporate risk-taking? Journal of Corporate Finance 23, 1-22.

Lobo, G.J., 2017. Accounting research in banking-a review. China Journal of Accounting Research 10, 1-7.

McConnell, J.J., Servaes, H., 1990. Additional evidence on equity ownership and corporate value. Journal of Financial economics 27, 595-612.

Minton, B.A., Taillard, J.P., Williamson, R., 2014. Financial expertise of the board, risk taking, and performance: Evidence from bank holding companies. Journal of Financial and Quantitative Analysis 49, 351-380.

Nakano, M., Nguyen, P., 2012. Board size and corporate risk taking: further evidence from Japan. Corporate Governance: An International Review 20, 369-387.

Ng, T.-H., Chong, L.-L., Ismail, H., 2012. Is the risk management committee only a procedural compliance? An insight into managing risk taking among insurance companies in Malaysia. The Journal of Risk Finance 14, 71-86. 
Nguyen, P., 2011. Corporate governance and risk-taking: Evidence from Japanese firms. Pacific-Basin Finance Journal 19, 278-297.

Nocco, B.W., Stulz, R.M., 2006. Enterprise risk management: Theory and practice. Journal of applied corporate finance 18, 8-20.

Petersen, M.A., 2009. Estimating standard errors in finance panel data sets: Comparing approaches. The Review of Financial Studies 22, 435-480.

Rogers, D.A., 2002. Does executive portfolio structure affect risk management? CEO risktaking incentives and corporate derivatives usage. Journal of Banking \& Finance 26, 271-295.

Rosenbaum, P.R., Rubin, D.B., 1983. The central role of the propensity score in observational studies for causal effects. Biometrika, 41-55.

Rosenstein, S., Wyatt, J.G., 1990. Outside directors, board independence, and shareholder wealth. Journal of financial economics 26, 175-191.

Shleifer, A., Vishny, R.W., 1986. Large shareholders and corporate control. Journal of political economy $94,461-488$.

Shleifer, A., Wolfenzon, D., 2002. Investor protection and equity markets. Journal of Financial Economics 66, 3-27.

Subramaniam, N., McManus, L., Zhang, J., 2009. Corporate governance, firm characteristics and risk management committee formation in Australian companies. Managerial Auditing Journal 24, 316-339.

Villalonga, B., Amit, R., 2006. How do family ownership, control and management affect firm value? Journal of financial Economics 80, 385-417.

Wright, P., Kroll, M., Krug, J.A., Pettus, M., 2007. Influences of top management team incentives on firm risk taking. Strategic Management Journal 28, 81-89.

Yatim, P., 2010. Board structures and the establishment of a risk management committee by Malaysian listed firms. Journal of Management \& Governance 14, 17-36.

Yermack, D., 1996. Higher market valuation of companies with a small board of directors. Journal of financial economics 40, 185-211.

Zahra, S.A., 2005. Entrepreneurial risk taking in family firms. Family business review 18, 23 40.

Zaman, M., 2001. Turnbull-generating undue expectations of the corporate governance role of audit committees. Managerial Auditing Journal 16, 5-9. 
Table 1 - Sample Distribution

\begin{tabular}{|l|c|}
\hline \multicolumn{1}{|c|}{ Details } & $\begin{array}{c}\text { Firm } \\
\text { Year }\end{array}$ \\
\hline Initial Sample 2001 -2013 & $\mathbf{1 3 , 4 8 8}$ \\
\hline Less: missing firms and years in matched DataStream and SIRCA & $\mathbf{5 , 9 5 8}$ \\
\hline Less: firm-year observations pertaining to financial institutes & $\mathbf{8 1 1}$ \\
\hline Less: No operational risk committees (neither a stand-alone nor a joint audit and risk committee). & $\mathbf{4 , 8 1 8}$ \\
\hline Final Sample & $\mathbf{1 , 9 0 1}$ \\
\hline
\end{tabular}

Table 2 - Panel A: Descriptive Statistics

\begin{tabular}{lccccc}
\hline Variable & Mean & Std. Dev. & Median & Min & Max \\
\hline$R C$ & 0.127 & 0.333 & 0.000 & 0.000 & 1.000 \\
$($ R\&D/TA $)$ & 0.016 & 0.071 & 0.000 & 0.000 & 1.074 \\
$\sigma($ MRET $)$ & 0.172 & 0.138 & 0.110 & 0.000 & 1.816 \\
$\sigma(R O A)$ & 0.137 & 0.330 & 0.050 & 0.000 & 5.818 \\
TOBIN'SQ & 0.709 & 0.212 & 0.746 & -2.391 & 1.115 \\
ROA & 0.064 & 0.351 & 0.197 & -0.301 & 1.024 \\
LOGSIZE & 10.931 & 2.138 & 11.80 & 3.136 & 18.157 \\
MTBV & 2.054 & 1.825 & 1.610 & -3.920 & 8.900 \\
LEV & 0.106 & 0.182 & 0.090 & 0.000 & 3.020 \\
CAPEXP & 0.089 & 0.112 & 0.040 & -0.520 & 0.567 \\
SALESCHANGE & 0.255 & 0.776 & 0.080 & -1.810 & 3.800 \\
LOGAGE & 2.438 & 0.618 & 2.400 & 0.000 & 3.714 \\
PM & -2.558 & 5.495 & 0.060 & -15.400 & 15.399 \\
MILLS & 2.842 & 0.749 & 2.740 & 0.000 & 5.798 \\
BODSIZE & 5.991 & 2.228 & 7.000 & 1.000 & 17.000 \\
BODIND & 4.353 & 2.172 & 5.000 & 0.000 & 15.000 \\
BIG4 & 0.595 & 0.491 & 1.000 & 0.000 & 1.000 \\
\hline
\end{tabular}

Note: $R C$ is a dummy variable assigned as a value of 1 when the firm has a stand-alone risk committee, otherwise $0 ;(R \& D / T A)$ indicates the total investment on research and development scaled by total assets; $\sigma(M R E T)$ is the standard deviation of monthly stock return; $\sigma(M R E T)$ indicates standard deviation of return on assets which is measure as the standard deviation of the income before tax and extraordinary items and scaled by total assets; Tobin's Q is measured as a ratio of the firm's market value to total assets; ROA is measured as the ratio of income before extraordinary items divided by total assets; LOGSIZE is firm size measured by the natural logarithm of total assets; $M T B V$ is market value of firm scaled by total equity; $L E V$ is firm leverage measured by total debt to total assets; CAPEXP is capital expenditure scaled by market value of assets; SALESCHANGE is sales growth measured by changes in sales scaled by total assets; LOGAGE is firm age measured by the natural logarithm of firm age since the firm was listed in ASX; $P M$ is the profit margin measured by the net income before extraordinary items and tax scaled by total sales; BODSIZE is the size of board directorship measured by the natural logarithm of total board size; BODIND is the representation of independent directors in the board measure as a ratio of total number of independent directors to total board size; BIG4 is audit quality, assigned as a value of 1 if the firm is audited by a big- 4 auditor, otherwise 0 . 
Table 2 - Panel B: Mean-difference Statistics

\begin{tabular}{lccc}
\hline Variables & $\begin{array}{c}\mathbf{R C}=\mathbf{0} \\
\mathbf{N}=\mathbf{1 6 6 0}\end{array}$ & $\begin{array}{c}\mathbf{R C = 1} \\
\mathbf{N}=\mathbf{2 4 1}\end{array}$ & $\begin{array}{c}\text { Mean Difference } \\
\text { (t-statistic) }\end{array}$ \\
\hline$($ R\&D/TA) & 0.019 & 0.0002 & $0.018(3.65)^{* * *}$ \\
$\sigma(M R E T)$ & 0.137 & 0.095 & $0.042(6.34)^{* * *}$ \\
$\sigma(R O A)$ & 0.099 & 0.032 & $0.067(4.97)^{* * *}$ \\
TOBIN'SQ & 0.600 & 0.725 & $-0.125(-8.70)^{* * *}$ \\
ROA & -0.061 & 0.015 & $-0.076(-3.09)^{* * *}$ \\
LOGSIZE & 11.75 & 13.51 & $-1.75(-13.14)^{* * *}$ \\
MTBV & 2.147 & 1.984 & $0.163(1.69)^{*}$ \\
LEV & 0.128 & 0.168 & $-0.04(-3.72)^{* * *}$ \\
CAPEXP & 0.083 & 0.075 & $0.007(1.06)$ \\
SALESCHANGE & 0.213 & 0.181 & $0.032(0.72)$ \\
LOGAGE & 2.357 & 2.599 & $-0.242(-5.38)^{* * *}$ \\
PM & -1.438 & -0.647 & $-0.791(-2.71)^{* *}$ \\
BODSIZE & 6.764 & 8.386 & $-1.622(-10.67)^{* * *}$ \\
BODIND & 5.175 & 6.502 & $-1.327(-8.94)^{* * *}$ \\
BIG4 & 0.729 & 0.822 & $-0.093(-3.79)^{* * *}$ \\
\hline
\end{tabular}

Note: See Table 2, Panel A for variable definition. $* * *, * *, *$ indicates $\mathrm{p}<0.01, \mathrm{p}<0.05, \mathrm{p}<0.10$ 
Table 2 - Panel C: Correlation analysis

\begin{tabular}{|c|c|c|c|c|c|c|c|c|c|c|c|c|c|c|c|c|}
\hline Variables & 1 & 2 & 3 & 4 & 5 & 6 & 7 & 8 & 9 & 10 & 11 & 12 & 13 & 14 & 15 & 16 \\
\hline$R C(1)$ & 1.00 & & & & & & & & & & & & & & & \\
\hline$(R \& D / T A)(2)$ & $-0.08 * * *$ & 1.00 & & & & & & & & & & & & & & \\
\hline$\sigma(M R E T)(3)$ & $-0.15^{* * *}$ & $0.16^{* * *}$ & 1.00 & & & & & & & & & & & & & \\
\hline$\sigma(R O A)(4)$ & $-0.12 * * *$ & $0.20 * * *$ & $0.26 * * *$ & 1.00 & & & & & & & & & & & & \\
\hline TOBIN'SQ (5) & $0.19^{* * *}$ & $0.08 * * *$ & $0.14 * * *$ & $0.11^{* * *}$ & 1.00 & & & & & & & & & & & \\
\hline$R O A(6)$ & $0.071^{* * *}$ & $0.31 * * *$ & $0.27^{* * * *}$ & $0.26^{* * *}$ & $0.085 * * *$ & 1.00 & & & & & & & & & & \\
\hline BODSIZE (7) & $0.24 * * *$ & $-0.07 * * *$ & $-0.26^{* * * *}$ & $-0.16^{* * *}$ & $-0.18 * *$ & $0.15^{* * *}$ & 1.00 & & & & & & & & & \\
\hline BODIND (8) & $0.20^{* * *}$ & $-0.07 * * *$ & $-0.27^{* * *}$ & $-0.16^{* * *}$ & $0.19^{* * *}$ & $0.16^{* * *}$ & $0.90^{* * *}$ & 1.00 & & & & & & & & \\
\hline BIG4 (8) & $0.07^{* *}$ & -0.03 & $-0.25^{* * *}$ & $-0.16^{* * *}$ & $0.13^{* * *}$ & $0.17 * * *$ & $0.30^{* * *}$ & $0.34^{* * * *}$ & 1.00 & & & & & & & \\
\hline LOGSIZE (10) & $0.29^{* * *}$ & $-0.24 * * *$ & $-0.43^{* * *}$ & $-0.36 * * *$ & $0.15^{* * *}$ & $0.40^{* * * *}$ & $0.66^{* * *}$ & $0.64 * * *$ & $0.44 * * *$ & 1.00 & & & & & & \\
\hline$L E V(11)$ & $0.10 * * *$ & $-0.15^{* * *}$ & $-0.22 * * *$ & $-0.22 * * *$ & $0.06^{* *}$ & $0.08^{* * *}$ & $0.17^{* * *}$ & $0.15^{* * *}$ & $0.14 * * *$ & $0.30 * * *$ & 1.00 & & & & & \\
\hline$M T B V(12)$ & -0.03 & $0.17 * * *$ & $-0.09 * * *$ & $0.14 * * *$ & 0.03 & $0.07 * * *$ & 0.00 & -0.02 & -0.01 & $-0.10 * * *$ & 0.01 & 1.00 & & & & \\
\hline CAPEXP (13) & -0.03 & $-0.13 * * *$ & $0.12^{* * * *}$ & -0.01 & $0.10^{* * *}$ & 0.00 & 0.03 & 0.02 & -0.03 & 0.02 & -0.02 & $0.08^{* * * *}$ & 1.00 & & & \\
\hline SALESCHANGE (14) & -0.02 & -0.01 & $0.07^{* *}$ & $0.11^{* * *}$ & $0.09 * * *$ & $0.08^{* * *}$ & $-0.06^{* *}$ & $-0.07^{* * *}$ & $-0.11 * * *$ & $-0.05^{* *}$ & 0.00 & $0.14 * * *$ & $0.14 * *$ & 1.00 & & \\
\hline LOGAGE (15) & $0.12 * * *$ & -0.02 & $-0.09 * * *$ & $-0.06 * *$ & $-0.07 * *$ & -0.03 & $0.23^{* * * *}$ & $0.29 * * *$ & $0.14 * * *$ & $0.29 * * *$ & 0.02 & $-0.07 * * *$ & 0.03 & $-0.13 * * *$ & 1.00 & \\
\hline
\end{tabular}

Note: See Table 2, Panel A for variable definition. $* * *, * *, *$ indicates $\mathrm{p}<0.01, \mathrm{p}<0.05, \mathrm{p}<0.10$ 
Table 3: Regression Analysis

\begin{tabular}{|c|c|c|c|c|c|c|c|}
\hline Variables & $\begin{array}{c}\text { First } \\
\text { Stage } \\
\text { DEP = } \\
\text { RC }\end{array}$ & $(R \& D / T A)_{t+1}$ & $\sigma(M R E T)_{t+1}$ & $\sigma(R O A)_{t+1}$ & $(R \& D / T A)_{t+1}$ & $\sigma(M R E T)_{t+1}$ & $\sigma(R O A)_{t+1}$ \\
\hline Constant & $\begin{array}{c}-5.217 * * * \\
{[-6.33]}\end{array}$ & $\begin{array}{c}0.021 * * * \\
{[10.85]}\end{array}$ & $\begin{array}{c}0.141 * * * \\
{[14.34]}\end{array}$ & $\begin{array}{c}0.099 * * * \\
{[9.24]}\end{array}$ & $\begin{array}{c}0.055 * * * \\
{[5.15]}\end{array}$ & $\begin{array}{c}0.409 * * * \\
{[10.27]}\end{array}$ & $\begin{array}{c}0.205 * * \\
{[2.74]}\end{array}$ \\
\hline BODSIZE & $\begin{array}{c}0.193 * * \\
{[2.66]}\end{array}$ & & & & & & \\
\hline BODIND & $\begin{array}{c}-0.234 * * * \\
{[-3.18]}\end{array}$ & & & & & & \\
\hline BIG4 & $\begin{array}{l}-0.316 \\
{[-1.43]}\end{array}$ & & & & & & \\
\hline LOGSIZE & $\begin{array}{c}0.307 * * * \\
{[4.79]}\end{array}$ & & & & $\begin{array}{c}-0.005 * * * \\
{[-5.26]}\end{array}$ & $\begin{array}{c}-0.018 * * * \\
{[-9.21]}\end{array}$ & $\begin{array}{c}-0.015 * * * \\
{[-3.90]}\end{array}$ \\
\hline LEV & $\begin{array}{c}1.239 * * \\
{[2.34]}\end{array}$ & & & & $\begin{array}{c}-0.024 * * \\
{[-2.29]}\end{array}$ & $\begin{array}{c}-0.042 * * \\
{[-2.77]}\end{array}$ & $\begin{array}{c}-0.085^{* *} \\
{[-2.99]}\end{array}$ \\
\hline$M T B V$ & $\begin{array}{l}-0.041 \\
{[-0.79]}\end{array}$ & & & & $\begin{array}{c}0.005 * * * \\
{[6.29]}\end{array}$ & $\begin{array}{c}-0.009 * * * \\
{[-8.18]}\end{array}$ & $\begin{array}{c}0.013 * * * \\
{[6.12]}\end{array}$ \\
\hline САРЕХР & & & & & $\begin{array}{c}-0.082 * * * \\
{[-5.71]}\end{array}$ & $\begin{array}{c}0.117 * * * \\
{[6.26]}\end{array}$ & $\begin{array}{l}0.026 \\
{[0.74]}\end{array}$ \\
\hline SALESCHANGE & & & & & $\begin{array}{c}0.001 \\
{[-0.10]}\end{array}$ & $\begin{array}{l}0.008 * * \\
{[2.74]}\end{array}$ & $\begin{array}{c}0.016^{* *} \\
{[2.88]}\end{array}$ \\
\hline LOGAGE & & & & & $\begin{array}{l}0.004^{*} \\
{[1.85]}\end{array}$ & $\begin{array}{l}0.001 \\
{[0.39]}\end{array}$ & $\begin{array}{l}0.002 \\
{[0.39]}\end{array}$ \\
\hline$P M$ & & & & & $\begin{array}{c}-0.002 * * * \\
{[-4.69]}\end{array}$ & $\begin{array}{c}-0.005 * * * \\
{[-8.76]}\end{array}$ & $\begin{array}{c}-0.002 * * \\
{[-2.47]}\end{array}$ \\
\hline$I M R$ & & & & & $\begin{array}{c}0.012^{* *} \\
{[2.08]}\end{array}$ & $\begin{array}{c}-0.016^{* *} \\
{[-2.28]}\end{array}$ & $\begin{array}{l}0.011 \\
{[0.82]}\end{array}$ \\
\hline$R C$ & & $\begin{array}{c}-0.018^{* * * *} \\
{[-3.21]}\end{array}$ & $\begin{array}{c}-0.033 * * * \\
{[-4.49]}\end{array}$ & $\begin{array}{c}-0.061 * * * \\
{[-3.96]}\end{array}$ & $\begin{array}{c}-0.014 * * \\
{[-2.34]}\end{array}$ & $\begin{array}{c}-0.014 * * \\
{[-2.30]}\end{array}$ & $\begin{array}{c}-0.023 * * \\
{[-2.01]}\end{array}$ \\
\hline $\begin{array}{l}\text { INDUSTRY } \\
\text { YEAR }\end{array}$ & $\begin{array}{l}\text { Controlled } \\
\text { Controlled }\end{array}$ & $\begin{array}{l}\text { Controlled } \\
\text { Controlled }\end{array}$ & $\begin{array}{l}\text { Controlled } \\
\text { Controlled } \\
\end{array}$ & $\begin{array}{l}\text { Controlled } \\
\text { Controlled }\end{array}$ & $\begin{array}{l}\text { Controlled } \\
\text { Controlled }\end{array}$ & $\begin{array}{l}\text { Controlled } \\
\text { Controlled }\end{array}$ & $\begin{array}{l}\text { Controlled } \\
\text { Controlled }\end{array}$ \\
\hline $\begin{array}{l}\text { F-statistics/LR } \\
\text { Chi2 }\end{array}$ & $319.47 * * *$ & 21.12 & $25.13 * * *$ & 23.21 & $16.91 * * *$ & $60.02 * * *$ & $32.79 * * *$ \\
\hline Probability & 0.000 & 0.000 & 0.000 & 0.000 & 0.000 & 0.000 & 0.000 \\
\hline Pseudo R-square & 22.20 & - & - & - & - & - & - \\
\hline $\begin{array}{l}\text { Adjusted R- } \\
\text { Square }\end{array}$ & - & 12.72 & 19.19 & 17.19 & 26.28 & 29.66 & 18.16 \\
\hline Observations & 1901 & 1901 & 1901 & 1901 & 1901 & 1901 & 1901 \\
\hline
\end{tabular}

Note: See Table 2, Panel A for variable definition. $* * *, * *, *$ indicates $\mathrm{p}<0.01, \mathrm{p}<0.05, \mathrm{p}<0.10$ 
Table 4: Regression Analysis

\begin{tabular}{|c|c|c|c|}
\hline Variables & $\begin{array}{c}\text { Dependent }= \\
F V A L=T O B I N ' S Q \\
\text { Coefficients }(t \text {-statistics) }\end{array}$ & $\begin{array}{c}\text { Dependent }= \\
\text { FVAL }=\text { ROA } \\
\text { Coefficients }(t \text {-statistics) }\end{array}$ & $V I F$ \\
\hline Constant & $\begin{array}{c}0.771 * * * \\
{[23.94]}\end{array}$ & $\begin{array}{c}-0.881 * * * \\
{[14.82]}\end{array}$ & \\
\hline BODSIZE & $\begin{array}{c}-0.015 * * \\
{[-2.31]}\end{array}$ & $\begin{array}{c}-0.037 * * * \\
{[-4.36]}\end{array}$ & 4.94 \\
\hline BODIND & $\begin{array}{c}0.009 * * \\
{[2.10]}\end{array}$ & $\begin{array}{c}0.003 \\
{[0.75]}\end{array}$ & 4.52 \\
\hline BIG4 & $\begin{array}{c}0.067 * * * \\
{[6.18]}\end{array}$ & $\begin{array}{c}-0.034 \\
{[-0.98]}\end{array}$ & 1.28 \\
\hline LOGSIZE & $\begin{array}{c}0.009 * * * \\
{[4.72]}\end{array}$ & $\begin{array}{c}0.101 * * * \\
{[12.21]}\end{array}$ & 1.05 \\
\hline$L E V$ & $\begin{array}{c}0.179 * * * \\
{[6.01]}\end{array}$ & $\begin{array}{c}0.124 * \\
{[1.90]}\end{array}$ & 1.17 \\
\hline$M T B V$ & $\begin{array}{c}-0.005 * * \\
{[-2.11]}\end{array}$ & $\begin{array}{c}0.014 * * \\
{[2.45]}\end{array}$ & 1.24 \\
\hline CAPEXP & $\begin{array}{c}0.005^{* *} \\
{[2.19]}\end{array}$ & $\begin{array}{l}-0.060 \\
{[-0.75]}\end{array}$ & 1.61 \\
\hline SALESCHANGE & $\begin{array}{c}0.015^{* *} \\
{[2.22]}\end{array}$ & $\begin{array}{c}0.292 * * \\
{[2.24]}\end{array}$ & 1.08 \\
\hline$L O G A G E$ & $\begin{array}{l}0.001 \\
{[0.12]}\end{array}$ & $\begin{array}{c}-0.055^{* * *} * \\
{[-4.32]}\end{array}$ & 1.03 \\
\hline$R C$ & $\begin{array}{c}0.101 * * * \\
{[7.54]}\end{array}$ & $\begin{array}{c}0.034 * * * \\
{[3.94]}\end{array}$ & 1.01 \\
\hline $\begin{array}{l}\text { INDUSTRY } \\
\text { YEAR }\end{array}$ & $\begin{array}{l}\text { Controlled } \\
\text { Controlled }\end{array}$ & $\begin{array}{l}\text { Controlled } \\
\text { Controlled }\end{array}$ & \\
\hline F-statistics/LR Chi2 & 23.53 & 38.18 & \\
\hline Probability & 0.000 & 0.000 & \\
\hline Pseudo R-square & - & - & \\
\hline Adjusted R-Square & 12.67 & 17.94 & \\
\hline Observations & 1901 & 1901 & \\
\hline
\end{tabular}

Note: See Table 2, Panel A for variable definition.

$* * *, * *, *$ indicates $\mathrm{p}<0.01, \mathrm{p}<0.05, \mathrm{p}<0.10$ 
Table 5: Propensity Score Match Results

\begin{tabular}{|c|c|c|c|c|c|}
\hline Variables & $(R \& D / T A)_{t+1}$ & $\sigma(M R E T)_{t+1}$ & $\sigma(R O A)_{t+1}$ & $\begin{array}{l}\text { Dep }=F V A L \\
T O B I N ' S Q\end{array}$ & $\begin{array}{l}\text { Dep }=F V A L \\
R O A\end{array}$ \\
\hline Constant & $\begin{array}{l}0.014 * \\
{[1.81]}\end{array}$ & $\begin{array}{l}0.25 * * * \\
{[6.32]}\end{array}$ & $\begin{array}{l}0.246 * * * \\
{[3.27]}\end{array}$ & $\begin{array}{l}0.745 * * * \\
{[20.98]}\end{array}$ & $\begin{array}{l}0.881 * * * \\
{[4.82]}\end{array}$ \\
\hline$R C$ & $\begin{array}{l}-0.009 * * * * \\
{[-3.58]}\end{array}$ & $\begin{array}{l}-0.044 * * * * \\
{[-3.91]}\end{array}$ & $\begin{array}{l}-0.197 * * * * \\
{[-5.22]}\end{array}$ & $\begin{array}{l}0.091 * * * \\
{[7.37]}\end{array}$ & $\begin{array}{l}0.032 * \\
{[1.79]}\end{array}$ \\
\hline LOGSIZE & $\begin{array}{l}-0.001 \\
{[-1.08]}\end{array}$ & $\begin{array}{l}-0.008^{* * * *} \\
{[-3.45]}\end{array}$ & $\begin{array}{l}-0.014 * * * \\
{[-2.99]}\end{array}$ & $\begin{array}{l}0.007 * * \\
{[2.42]}\end{array}$ & $\begin{array}{l}0.101 * * * \\
{[16.61]}\end{array}$ \\
\hline$L E V$ & $\begin{array}{l}-0.013 * * \\
{[-2.43]}\end{array}$ & $\begin{array}{l}-0.048 * \\
{[-1.86]}\end{array}$ & $\begin{array}{l}-0.067^{*} \\
{[-1.73]}\end{array}$ & $\begin{array}{l}0.185^{* * * *} \\
{[6.25]}\end{array}$ & $\begin{array}{l}0.109 * * \\
{[2.45]}\end{array}$ \\
\hline$M T B V$ & $\begin{array}{l}0.001 * * \\
{[2.38]}\end{array}$ & $\begin{array}{l}-0.010 * * * \\
{[-3.86]}\end{array}$ & $\begin{array}{l}0.019 * * * \\
{[3.69]}\end{array}$ & $\begin{array}{l}-0.003 \\
{[-1.51]}\end{array}$ & $\begin{array}{l}0.012^{* *} \\
{[2.53]}\end{array}$ \\
\hline CAPEX & $\begin{array}{l}-0.014 * \\
{[-1.74]}\end{array}$ & $\begin{array}{l}0.253^{* * * *} \\
{[6.55]}\end{array}$ & $\begin{array}{l}-0.085 \\
{[-1.23]}\end{array}$ & $\begin{array}{l}0.163 * * * \\
{[3.90]}\end{array}$ & $\begin{array}{l}-0.061^{*} \\
{[-1.71]}\end{array}$ \\
\hline SALESCHANGE & $\begin{array}{l}0.001 \\
{[0.98]}\end{array}$ & $\begin{array}{l}-0.007 \\
{[-1.10]}\end{array}$ & $\begin{array}{l}0.026^{*} \\
{[1.87]}\end{array}$ & $\begin{array}{l}0.010 \\
{[1.43]}\end{array}$ & $\begin{array}{l}0.029 * * \\
{[2.24]}\end{array}$ \\
\hline$L O G A G E$ & $\begin{array}{l}0.001 \\
{[0.11]}\end{array}$ & $\begin{array}{l}-0.004 \\
{[-0.55]}\end{array}$ & $\begin{array}{l}0.034 * * \\
{[2.62]}\end{array}$ & $\begin{array}{l}-0.001 \\
{[-0.12]}\end{array}$ & $\begin{array}{l}-0.055 * * * \\
{[-4.41]}\end{array}$ \\
\hline$P M$ & $\begin{array}{l}0.002 \\
{[0.64]}\end{array}$ & $\begin{array}{l}-0.007 * * * \\
{[-4.95]}\end{array}$ & $\begin{array}{l}-0.013 * * * \\
{[-4.92]}\end{array}$ & - & - \\
\hline BODSIZE & & & & $\begin{array}{l}-0.011 * * \\
{[-2.45]}\end{array}$ & $\begin{array}{l}-0.037 * * * \\
{[-3.99]}\end{array}$ \\
\hline BODIND & & & & $\begin{array}{l}0.009 * * \\
{[2.03]}\end{array}$ & $\begin{array}{l}0.002 \\
{[0.75]}\end{array}$ \\
\hline BIG4 & & & & $\begin{array}{l}-0.058 * * * \\
{[-5.46]}\end{array}$ & $\begin{array}{l}-0.025 \\
{[-.1 .21]}\end{array}$ \\
\hline $\begin{array}{l}\text { INDUSTRY } \\
\text { YEAR }\end{array}$ & $\begin{array}{l}\text { Controlled } \\
\text { Controlled }\end{array}$ & $\begin{array}{l}\text { Controlled } \\
\text { Controlled }\end{array}$ & $\begin{array}{l}\text { Controlled } \\
\text { Controlled }\end{array}$ & $\begin{array}{l}\text { Controlled } \\
\text { Controlled }\end{array}$ & $\begin{array}{l}\text { Controlled } \\
\text { Controlled }\end{array}$ \\
\hline $\begin{array}{l}\text { F-statistics } \\
\text { Adj R-squared } \\
\mathrm{N} \\
\end{array}$ & $\begin{array}{l}5.20 * * * \\
0.06 \\
482 \\
\end{array}$ & $\begin{array}{l}8.55^{* * * *} \\
0.36 \\
482 \\
\end{array}$ & $\begin{array}{l}6.17 * * * \\
0.29 \\
482 \\
\end{array}$ & $\begin{array}{l}24.73 * * * \\
0.18 \\
482 \\
\end{array}$ & $\begin{array}{l}38.08 * * * \\
0.21 \\
482 \\
\end{array}$ \\
\hline
\end{tabular}

Note: See Table 2, Panel A for variable definition. $* * *, * *, *$ indicates $\mathrm{p}<0.01, \mathrm{p}<0.05, \mathrm{p}<0.10$ 
Table 6: Robustness test results (additional test b \& c)

\begin{tabular}{|c|c|c|c|c|c|c|}
\hline \multicolumn{4}{|c|}{$\%$ of $R C$ independence } & \multicolumn{3}{|c|}{ Missing $R \& D$} \\
\hline Variables & $(R \& D / T A)_{t+1}$ & $\sigma(M R E T)_{t+1}$ & $\sigma(R O A)_{t+1}$ & $(R \& D / T A)_{t+1}$ & $\begin{array}{c}\text { Dep. variable } \\
=T O B I N ' S Q\end{array}$ & Dep. variable $=$ ROA \\
\hline Constant & $\begin{array}{l}0.005^{* * * *} \\
{[5.03]}\end{array}$ & $\begin{array}{l}0.321 * * * \\
{[4.68]}\end{array}$ & $\begin{array}{l}0.351 * * * \\
{[12.66]}\end{array}$ & $\begin{array}{l}0.128 * * * \\
{[3.27]}\end{array}$ & $\begin{array}{l}0.705 * * * \\
{[6.01]}\end{array}$ & $\begin{array}{l}0.841 * * * \\
{[5.12]}\end{array}$ \\
\hline$R C$ & - & - & - & $\begin{array}{l}-0.069 * * \\
{[-2.11]}\end{array}$ & $\begin{array}{l}0.027 * \\
{[1.79]}\end{array}$ & $\begin{array}{l}0.031 * * \\
{[2.29]}\end{array}$ \\
\hline$\% R C \_$independence & $\begin{array}{l}-0.003 * \\
{[-1.71]}\end{array}$ & $\begin{array}{l}-0.019 * * \\
{[-2.04]}\end{array}$ & $\begin{array}{l}-0.057 * * \\
{[-2.74]}\end{array}$ & - & - & - \\
\hline LOGSIZE & $\begin{array}{l}-0.004 * * * \\
{[-5.85]}\end{array}$ & $\begin{array}{l}-0.016 * * * \\
{[-6.87]}\end{array}$ & $\begin{array}{l}-0.025 * * * \\
{[-11.36]}\end{array}$ & $\begin{array}{l}-0.011 * * * \\
{[-3.39]}\end{array}$ & $\begin{array}{l}0.017 * * * \\
{[3.98]}\end{array}$ & $\begin{array}{l}0.028 * * * \\
{[3.85]}\end{array}$ \\
\hline$L E V$ & $\begin{array}{l}-0.023 * * \\
{[-2.27]}\end{array}$ & $\begin{array}{l}-0.027 * * \\
{[-2.05]}\end{array}$ & $\begin{array}{l}-0.124 * * * \\
{[-4.42]}\end{array}$ & $\begin{array}{l}-0.101 * * \\
{[-2.05]}\end{array}$ & $\begin{array}{l}0.095 \\
{[1.37]}\end{array}$ & $\begin{array}{l}0.109 \\
{[1.21]}\end{array}$ \\
\hline$M T B V$ & $\begin{array}{l}0.006 * * * \\
{[6.98]}\end{array}$ & $\begin{array}{l}-0.009 * * * \\
{[-7.99]}\end{array}$ & $\begin{array}{l}0.011 * * * \\
{[4.61]}\end{array}$ & $\begin{array}{l}0.009 * * \\
{[2.87]}\end{array}$ & $\begin{array}{l}0.003 \\
{[0.75]}\end{array}$ & $\begin{array}{l}0.002 \\
{[0.97]}\end{array}$ \\
\hline CAPEX & $\begin{array}{l}-0.104 * * * \\
{[-7.40]}\end{array}$ & $\begin{array}{l}0.094 * * * \\
{[5.16]}\end{array}$ & $\begin{array}{l}-0.076^{*} \\
{[-1.91]}\end{array}$ & $\begin{array}{l}-0.234 * * * \\
{[3.87]}\end{array}$ & $\begin{array}{l}-0.051 \\
{[-1.46]}\end{array}$ & $\begin{array}{l}-0.037 \\
{[-1.11]}\end{array}$ \\
\hline SALESCHANGE & $\begin{array}{l}0.001 \\
{[0.09]}\end{array}$ & $\begin{array}{l}0.009 * * * \\
{[3.30]}\end{array}$ & $\begin{array}{l}0.027 * * * \\
{[4.38]}\end{array}$ & $\begin{array}{l}0.029 * * \\
{[2.21]}\end{array}$ & $\begin{array}{l}0.016 * \\
{[1.86]}\end{array}$ & $\begin{array}{l}0.015 \\
{[1.36]}\end{array}$ \\
\hline$L O G A G E$ & $\begin{array}{l}0.004 * * \\
{[2.04]}\end{array}$ & $\begin{array}{l}0.003 \\
{[0.85]}\end{array}$ & $\begin{array}{l}0.015^{* *} \\
{[2.37]}\end{array}$ & $\begin{array}{l}0.019 * * \\
{[2.03]}\end{array}$ & $\begin{array}{l}0.032 * * \\
{[2.00]}\end{array}$ & $\begin{array}{l}0.038 * * \\
{[2.17]}\end{array}$ \\
\hline$P M$ & $\begin{array}{l}-0.004 * * * \\
{[-5.03]}\end{array}$ & $\begin{array}{l}-0.006^{* * * *} \\
{[-12.52]}\end{array}$ & $\begin{array}{l}-0.006 * * * \\
{[-6.25]}\end{array}$ & $\begin{array}{l}-0.012 * * * \\
{[-8.21]}\end{array}$ & - & - \\
\hline BODSIZE & - & - & - & - & $\begin{array}{l}-0.015 * \\
{[-1.75]}\end{array}$ & $\begin{array}{l}-0.021 * \\
{[-1.69]}\end{array}$ \\
\hline BODIND & - & - & - & - & $\begin{array}{l}0.008^{*} \\
{[1.81]}\end{array}$ & $\begin{array}{l}0.003^{*} \\
{[1.71]}\end{array}$ \\
\hline$B I G 4$ & - & - & - & - & $\begin{array}{l}-0.066 \text { *** } \\
{[-3.99]}\end{array}$ & $\begin{array}{l}-0.061 * * * \\
{[4.21]}\end{array}$ \\
\hline INDUSTRY & Controlled & Controlled & Controlled & Controlled & Controlled & Controlled \\
\hline$Y E A R$ & Controlled & Controlled & Controlled & Controlled & Controlled & Controlled \\
\hline F-statistics & $42.10 * * *$ & $95.05 * * *$ & $52.03 * * *$ & $28.96 * * *$ & $12.67 * * *$ & $13.24 * * *$ \\
\hline Adj R-squared & $13.85 \%$ & $28.55 \%$ & $17.83 \%$ & $43.19 \%$ & $13.47 \%$ & $16.24 \%$ \\
\hline $\mathrm{N}$ & 1901 & 1901 & 1901 & 348 & 348 & 348 \\
\hline
\end{tabular}

Note: See Table 2, Panel A for variable definition. $* * *, * *, *$ indicates $\mathrm{p}<0.01, \mathrm{p}<0.05, \mathrm{p}<0.10$ 
Table 7: Robustness test results (additional test d \& e)

\begin{tabular}{|c|c|c|c|c|c|c|}
\hline \multirow[b]{2}{*}{ Variables } & \multicolumn{3}{|c|}{ FIRMSIZE $>$ Median=1, Otherwise 0} & \multicolumn{3}{|c|}{$R C=1 \& N O \_R C=0$} \\
\hline & $(R \& D / T A)_{t+1}$ & $\sigma(M R E T)_{t+1}$ & $\sigma(R O A)_{t+1}$ & $(R \& D / T A)_{t+1}$ & $\sigma(M R E T)_{t+1}$ & $\overline{\sigma(R O A)_{t+1}}$ \\
\hline Constant & $\begin{array}{l}0.054 * * * \\
{[3.72]}\end{array}$ & $\begin{array}{l}0.321 * * * \\
{[5.72]}\end{array}$ & $\begin{array}{l}0.223 * * * \\
{[6.48]}\end{array}$ & $\begin{array}{l}0.039 * * * \\
{[3.32]}\end{array}$ & $\begin{array}{l}0.451^{* * * *} \\
{[9.79]}\end{array}$ & $\begin{array}{l}0.241 * * * \\
{[5.52]}\end{array}$ \\
\hline$R C$ & $\begin{array}{l}-0.008^{* * *} \\
{[-1.99]}\end{array}$ & $\begin{array}{l}-0.013^{*} \\
{[-1.79]}\end{array}$ & $\begin{array}{l}-0.029 \\
{[-3.77]}\end{array}$ & $\begin{array}{l}-0.007 * * * * \\
{[-2.91]}\end{array}$ & $\begin{array}{l}-0.018^{* * * *} \\
{[-3.52]}\end{array}$ & $\begin{array}{l}-0.031 * * \\
{[-2.10]}\end{array}$ \\
\hline LOGSIZE & $\begin{array}{l}-0.004 * * * \\
{[-5.35]}\end{array}$ & $\begin{array}{l}-0.014 * * * \\
{[-11.97]}\end{array}$ & $\begin{array}{l}-0.023^{* * * *} \\
{[-7.60]}\end{array}$ & $\begin{array}{l}-0.002 * * \\
{[-2.51]}\end{array}$ & $\begin{array}{l}-0.012 * * * \\
{[-8.95]}\end{array}$ & $\begin{array}{l}-0.037 * * * \\
{[-13.71]}\end{array}$ \\
\hline$L E V$ & $\begin{array}{l}-0.027 * * * \\
{[-3.09]}\end{array}$ & $\begin{array}{l}-0.027 * * \\
{[-2.16]}\end{array}$ & $\begin{array}{l}-0.110 * * * \\
{[-5.29]}\end{array}$ & $\begin{array}{l}-0.006^{*} \\
{[-1.78]}\end{array}$ & $\begin{array}{l}-0.017 \\
{[-0.74]}\end{array}$ & $\begin{array}{l}-0.025 \\
{[-0.70]}\end{array}$ \\
\hline$M T B V$ & $\begin{array}{l}0.005^{* * * *} \\
{[6.92]}\end{array}$ & $\begin{array}{l}-0.011 * * * \\
{[-9.65]}\end{array}$ & $\begin{array}{l}0.009 * * * \\
{[5.40]}\end{array}$ & $\begin{array}{l}0.005^{* * *} \\
{[5.95]}\end{array}$ & $\begin{array}{l}-0.008^{* * * *} \\
{[-7.62]}\end{array}$ & $\begin{array}{l}0.030^{* *} \\
{[10.59]}\end{array}$ \\
\hline CAPEX & $\begin{array}{l}-0.093 * * * \\
{[-7.40]}\end{array}$ & $\begin{array}{l}0.111^{* * * *} \\
{[6.45]}\end{array}$ & $\begin{array}{l}-0.041 \\
{[-1.38]}\end{array}$ & $\begin{array}{l}-0.083^{* * *} \\
{[-9.40]}\end{array}$ & $\begin{array}{l}-0.033^{* *} \\
{[-2.30]}\end{array}$ & $\begin{array}{l}-0.131 * * * \\
{[-3.51]}\end{array}$ \\
\hline SALESCHANGE & $\begin{array}{l}0.002 \\
{[0.70]}\end{array}$ & $\begin{array}{l}0.009^{* * *} \\
{[3.40]}\end{array}$ & $\begin{array}{l}0.025^{* * *} \\
{[5.44]}\end{array}$ & $\begin{array}{l}-0.001 \\
{[-0.81]}\end{array}$ & $\begin{array}{l}0.009 * * * \\
{[4.29]}\end{array}$ & $\begin{array}{l}0.027 * * * \\
{[4.62]}\end{array}$ \\
\hline$L O G A G E$ & $\begin{array}{l}0.002 \\
{[0.82]}\end{array}$ & $\begin{array}{l}-0.001 \\
{[-0.92]}\end{array}$ & $\begin{array}{l}0.002 \\
{[0.40]}\end{array}$ & $\begin{array}{l}-0.005^{* *} \\
{[-2.83]}\end{array}$ & $\begin{array}{l}0.008^{* *} \\
{[2.50]}\end{array}$ & $\begin{array}{l}-0.011 \\
{[-1.37]}\end{array}$ \\
\hline$P M$ & $\begin{array}{l}-0.003 * * * \\
{[-8.88]}\end{array}$ & $\begin{array}{l}-0.005^{* * *} \\
{[-12.11]}\end{array}$ & $\begin{array}{l}-0.006^{* * *} \\
{[-7.99]}\end{array}$ & $\begin{array}{l}-0.002 * * \\
{[-2.07]}\end{array}$ & $\begin{array}{l}-0.003 * * * \\
{[-10.45]}\end{array}$ & $\begin{array}{l}-0.006 * * * \\
{[-6.53]}\end{array}$ \\
\hline $\begin{array}{l}\text { INDUSTRY } \\
\text { YEAR }\end{array}$ & $\begin{array}{l}\text { Controlled } \\
\text { Controlled }\end{array}$ & $\begin{array}{l}\text { Controlled } \\
\text { Controlled }\end{array}$ & $\begin{array}{l}\text { Controlled } \\
\text { Controlled }\end{array}$ & $\begin{array}{l}\text { Controlled } \\
\text { Controlled }\end{array}$ & $\begin{array}{l}\text { Controlled } \\
\text { Controlled }\end{array}$ & $\begin{array}{l}\text { Controlled } \\
\text { Controlled }\end{array}$ \\
\hline $\begin{array}{l}\text { F-statistics } \\
\text { Adj R-squared } \\
\mathrm{N}\end{array}$ & $\begin{array}{l}13.68 * * * \\
16.35 \% \\
1901\end{array}$ & $\begin{array}{l}35.35^{* * * *} \\
36.29 \% \\
1901\end{array}$ & $\begin{array}{l}17.63 * * * \\
19.65 \% \\
1901\end{array}$ & $\begin{array}{l}10.88 * * * \\
10.82 \% \\
482\end{array}$ & $\begin{array}{l}65.78 * * * \\
37.48 \% \\
482\end{array}$ & $\begin{array}{l}27.54 * * * \\
13.65 \% \\
482\end{array}$ \\
\hline
\end{tabular}

Note: See Table 2, Panel A for variable definition. ***, **, * indicates $\mathrm{p}<0.01, \mathrm{p}<0.05, \mathrm{p}<0.10$ 
Table 8: Regression Analysis including the Risk Committee Characteristics

\begin{tabular}{|c|c|c|c|c|c|}
\hline Variables & $\begin{array}{l}\text { Dep }=R I S K \\
(R \& D / T A)_{t+1}\end{array}$ & $\begin{array}{l}D e p=R I S K \\
\sigma(M R E T)_{t+1}\end{array}$ & $\begin{array}{l}D e p=R I S K \\
\sigma(R O A)_{t+1}\end{array}$ & $\begin{array}{l}\text { Dep }=F V A L \\
\text { TOBIN'S Q }\end{array}$ & $\begin{array}{l}D e p=F V A L \\
\mathrm{ROA}\end{array}$ \\
\hline Constant & $\begin{array}{l}0.057 * * \\
{[2.01]}\end{array}$ & $\begin{array}{l}0.352 * * * \\
{[15.23]}\end{array}$ & $\begin{array}{l}0.371 \text { *** } \\
{[7.12]}\end{array}$ & $\begin{array}{l}0.067 * * \\
{[6.25]}\end{array}$ & $\begin{array}{l}0.317 * * * \\
{[6.98]}\end{array}$ \\
\hline$R C$ & $\begin{array}{l}-0.005 * * \\
{[-2.29]}\end{array}$ & $\begin{array}{l}-0.014 * * \\
{[-2.24]}\end{array}$ & $\begin{array}{l}-0.030 * * \\
{[-2.17]}\end{array}$ & $\begin{array}{l}0.024 * * * \\
{[2.38]}\end{array}$ & $\begin{array}{l}0.009 * * * \\
{[4.28]}\end{array}$ \\
\hline LOGSIZE & $\begin{array}{l}-0.006 * * * \\
{[-5.97]}\end{array}$ & $\begin{array}{l}-0.016^{* * * *} \\
{[-14.21]}\end{array}$ & $\begin{array}{l}-0.274 * * * \\
{[-11.49]}\end{array}$ & $\begin{array}{l}0.013 * \\
{[1.96]}\end{array}$ & $\begin{array}{l}0.079 * * * \\
{[13.82]}\end{array}$ \\
\hline$L E V$ & $\begin{array}{l}-0.024 * * \\
{[-2.34]}\end{array}$ & $\begin{array}{l}-0.021 * \\
{[-1.69]}\end{array}$ & $\begin{array}{l}-0.099 * * * \\
{[-3.48]}\end{array}$ & $\begin{array}{l}-0.111^{*} \\
{[-1.75]}\end{array}$ & $\begin{array}{l}-0.075 \\
{[-1.42]}\end{array}$ \\
\hline$M T B V$ & $\begin{array}{l}0.006 * * * \\
{[6.52]}\end{array}$ & $\begin{array}{l}-0.010 * * * \\
{[-9.03]}\end{array}$ & $\begin{array}{l}0.012 * * * \\
{[5.25]}\end{array}$ & $\begin{array}{l}-0.134 * * * \\
{[-5.25]}\end{array}$ & $\begin{array}{l}0.016 * * * \\
{[3.68]}\end{array}$ \\
\hline CAPEX & $\begin{array}{l}-0.107 * * * \\
{[-7.29]}\end{array}$ & $\begin{array}{l}0.099 * * * \\
{[5.53]}\end{array}$ & $\begin{array}{l}-0.064 \\
{[-1.55]}\end{array}$ & $\begin{array}{l}-0.147 * \\
{[-1.68]}\end{array}$ & $\begin{array}{l}0.058 \\
{[0.77]}\end{array}$ \\
\hline SALESCHANGE & $\begin{array}{l}-0.001 \\
{[-0.12]}\end{array}$ & $\begin{array}{l}0.008 * * \\
{[2.92]}\end{array}$ & $\begin{array}{l}0.026 * * * \\
{[4.20]}\end{array}$ & $\begin{array}{l}-0.033 * * \\
{[-2.38]}\end{array}$ & $\begin{array}{l}0.011 \\
{[0.98]}\end{array}$ \\
\hline$L O G A G E$ & $\begin{array}{l}0.005^{*} \\
{[1.93]}\end{array}$ & $\begin{array}{l}0.003 \\
{[0.96]}\end{array}$ & $\begin{array}{l}0.018 * * \\
{[2.89]}\end{array}$ & $\begin{array}{l}0.026^{*} \\
1.76]\end{array}$ & $\begin{array}{l}-0.389 * * * \\
{[-3.98]}\end{array}$ \\
\hline$P M$ & $\begin{array}{l}-0.004 * * * \\
{[-9.74]}\end{array}$ & $\begin{array}{l}-0.005 * * * \\
{[-12.34]}\end{array}$ & $\begin{array}{l}-0.006 * * * \\
{[-5.67]}\end{array}$ & - & - \\
\hline BODSIZE & & & & $\begin{array}{l}-0.008 \\
{[-0.91]}\end{array}$ & $\begin{array}{l}-0.032 * * * \\
{[-4.12]}\end{array}$ \\
\hline BODIND & & & & $\begin{array}{l}0.007 \\
{[0.81]}\end{array}$ & $\begin{array}{l}0.002 \\
{[0.29]}\end{array}$ \\
\hline BIG4 & & & & $\begin{array}{l}-0.038^{*} \\
{[-1.73]}\end{array}$ & $\begin{array}{l}-0.054 * * \\
{[-2.11]}\end{array}$ \\
\hline FINEXP & $\begin{array}{l}0.008 * \\
{[1.79]}\end{array}$ & $\begin{array}{l}-0.015 \\
{[-1.22]}\end{array}$ & $\begin{array}{l}-0.058 * * \\
{[-2.18]}\end{array}$ & $\begin{array}{l}0.019 \\
{[0.21]}\end{array}$ & $\begin{array}{l}0.021 \\
{[0.33]}\end{array}$ \\
\hline RISKTEN & $\begin{array}{l}-0.002 * \\
{[-1.69]}\end{array}$ & $\begin{array}{l}-0.002 * * * \\
{[-3.71]}\end{array}$ & $\begin{array}{l}-0.007 * * * \\
{[-4.52]}\end{array}$ & $\begin{array}{l}-0.034 \\
{[-0.91]}\end{array}$ & $\begin{array}{l}-0.009 \\
{[1.61]}\end{array}$ \\
\hline RISKBUSY & $\begin{array}{l}0.001 * \\
{[1.74]}\end{array}$ & $\begin{array}{l}0.007 \\
{[1.05]}\end{array}$ & $\begin{array}{l}0.003^{*} \\
{[1.94]}\end{array}$ & $\begin{array}{l}0.003 \\
{[0.75]}\end{array}$ & $\begin{array}{l}0.015 \\
{[0.87]}\end{array}$ \\
\hline $\begin{array}{l}\text { INDUSTRY } \\
\text { YEAR }\end{array}$ & $\begin{array}{l}\text { Controlled } \\
\text { Controlled }\end{array}$ & $\begin{array}{l}\text { Controlled } \\
\text { Controlled }\end{array}$ & $\begin{array}{l}\text { Controlled } \\
\text { Controlled }\end{array}$ & $\begin{array}{l}\text { Controlled } \\
\text { Controlled }\end{array}$ & $\begin{array}{l}\text { Controlled } \\
\text { Controlled }\end{array}$ \\
\hline $\begin{array}{l}\text { F-statistics } \\
\text { Adj R-squared } \\
\mathrm{N}\end{array}$ & $\begin{array}{l}12.93 * * * \\
0.17 \\
1901\end{array}$ & $\begin{array}{l}37.23 * * * \\
0.36 \\
1901\end{array}$ & $\begin{array}{l}17.31 * * * \\
0.23 \\
1901\end{array}$ & $\begin{array}{l}31.67 * * * \\
0.37 \\
1901\end{array}$ & $\begin{array}{l}34.57 * * * \\
0.42 \\
1901\end{array}$ \\
\hline
\end{tabular}

Note: See Table 2, Panel A for the description/definition of all the variables except FINEXP, RISKTEN and RISKBUSY. FINEXP is a continuous variable defined as the total number of director with previous experience \& expertise as CFO, CEO, or other financial executive positions or holding professional affiliation as CFA, FCA, FCMA, CPA and Ph.D. etc., RISKTEN is defined as the average number of years engaged as risk committee members, and RISKBUSY is defined as the average number of outside directorial position held by the risk committee members.

$* * *, * *, *$ indicates $\mathrm{p}<0.01, \mathrm{p}<0.05, \mathrm{p}<0.10$ 